\title{
Remote Monitoring of European Grapevine Moth, Lobesia botrana (Lepidoptera: Tortricidae) Population Using Camera-Based Pheromone Traps in Vineyards
}

\author{
Levent Ünlü1,a, Bayram Akdemir²,b, Ekrem Ögür, ${ }^{1, c, *}$, İnci Şahin ${ }^{1, d}$ \\ ${ }^{I}$ Department of Plant Protection, Faculty of Agriculture, Selçuk University, 42250 Konya, Turkey \\ ${ }^{2}$ Department of Electrical-Electronic Engineering, Faculty of Engineering, Selçuk University, 42250 Konya, Turkey
} *Corresponding author

A R T I C L E I N F O
Research Article

Received : 05/12/2018
Accepted : 18/02/2019

A B S T R A C T

This study presents a new sex pheromone trap for European Grapevine Moth, Lobesia botrana, to monitor its field population without direct field observations in Turkey. The study was conducted in Hadim and Taşkent (Konya) districts in 2016. Viticulture has been carried out for many years in both districts where the maximum vineyards are located. Due to the distance to the center and the difficulty of transportation to these districts, there has not been conducted any detailed studies until today. Therefore, this study about L. botrana, which is harmful in these vineyards, was planned. In order to monitor the pest population, the cameras were placed onto the pheromone traps, and it was tried to get information about the population development of the pest via internet without going to the vineyards. For this purpose, four locations in Hadim and one location in Taşkent district were selected and one pheromone trap was established in each location before the bud burst in vineyards. The camera was placed on each pheromone trap and was linked with vMEyeIPC program via internet. The time of first adult flight and the population development of adult $L$. botrana were determined. The first adult flight began at the beginning (7/4/2016) and in the middle of April (15/4/2016) in Hadim and Taşkent, respectively. The number of offspring and the maximum number of pest individuals caught in traps were recorded in vineyards in both districts.

\section{Camera}

European grapevine moth

Lobesia botrana

Pheromone

Vineyard

ulevent@selcuk.edu.tr

ekremogur@selcuk.edu.tr
(iD) https://orcid.org/0000-0002-4365-6283

iD https://orcid.org/0000-0002-8242-2754 b@bakdemir@selcuk.edu.tr

d@incisahin@selcuk.edu.tr
(iD https://orcid.org/0000-0002-0565-2345 (iD) https://orcid.org/0000-0002-4481-2807

(c) (1) (8) This work is licensed under Creative Commons Attribution 4.0 International License

\section{Introduction}

Since the discovery of the first insect pheromone by researchers in Germany, approximately 60 years have passed and there has been much progress in their development and use in insect pest management over the last three decades (Jones, 2014). In crop protection, one of the most important steps is monitoring pest insect populations, especially monitoring with traps is prevalent in pest management programs worldwide (Lopez et al., 2012; Priya et al., 2013; Upadhyay and Ingole, 2014; Raphael and Maheswari, 2016; Goldshtein et al., 2017). In particular, for monitoring the flight activity of fruit moths, sex pheromone traps are basic devices. They enable us to follow the pest population (emergence, first flight and changes in the number of adults etc.) in monitored area (Hari, 2014).

Using sex pheromone traps requires periodic visits to the field by a human operator in order to visual observation and recording of males captured in the traps in traditional monitoring of insect pests. This is a labor-intensive, time consuming and expensive implementation, especially for large orchards/vineyards or fields hard to reach. So, to find an affordable system performing this duty in a more efficient way would give great advantage while monitoring insect pest populations (Tirelli et al., 2011; Lopez et al., 2012; Priya et al., 2013; Upadhyay and Ingole, 2014; Raphael and Maheswari, 2016; Potamitis et al., 2014).

To minimize these efforts, some studies have brought into focus on the potential using of cameras for monitoring insect pest in recent decades (Jiang et al., 2008; Martin et al., 2008; Guarnieri et al., 2011; Fukatsu et al., 2012; Lopez et al., 2012; Priya et al., 2013; Selby et al., 2014; Upadhyay and Ingole, 2014; Azfar et al., 2015; Ding and Taylor, 2016; Raphael and Maheswari, 2016; Rassati et al, 2016; Goldshtein et al. 2017). In these studies, the pests were counted either automatically by software (Fukatsu et al., 2012; Priya et al., 2013; Upadhyay and Ingole, 2014; Potamitis and Rigakis, 2015; Ding and Taylor, 2016; Goldshtein et al. 2017) or manually by human experts (Guarnieri et al., 2011; Rassati et al, 2016). 
Grape is an important fruit used for many purposes besides its use as edible and dried. According to OIV (International Organisation of Vine and Wine) 2017 report China, Italy, USA, France, Spain and Turkey are on the first rank of producing grape in the world (Anonymous, 2017). In Turkey, Aegean region is the center of viticulture and followed by Mediterranean, Southeastern and Central Anatolia region, respectively (Arslan, 2015).

Lobesia botrana Denis and Schiffermüller (Lepidoptera: Tortricidae), commonly known as European grapevine moth, is one of the most devastating pests of grape in all vineyards, leading to serious fruit damage throughout the whole of Turkey (Mamay and Çakır, 2014;Turanl1, 2017). Not only in Turkey, but also it's a key pest of grape in most vineyard regions worldwide (Lucchi et al., 2018b). Accurate and timely monitoring is critical to effectively control of pest insects in crop protection (Tirelli et al., 2011). In order to apply suitable control methods on time, getting information about the insect populations is crucial (Lopez et al., 2012; Raphael and Maheswari, 2016). The management of this pest is based on forecasting and early warning systems. Researchers are benefit from the adult population development of the pest with pheromone traps, the sum of effective temperatures, following the hatching of the eggs and phenological records in early warning systems. In recent years, pheromone traps are considered a reliable and effective strategy to control L. botrana (Lucchi et al., 2018a). Especially, mating disruption is successfully used as an effective control tool to fight $L$. botrana populations in vineyards (Lucchi et al., 2018b).

The distances of Hadim and Taşkent (Konya) district, where the study was carried out, to the city center are 125 and $135 \mathrm{~km}$, respectively, and the distance between them is $12 \mathrm{~km}$ (Anonymous, 2015a). In these districts, there is a total of 40.446 da viticulture areas and this constitute approximately the $41 \%$ of the total viticulture area of Konya province (99.182 da) (Anonymous, 2015b,c,d). However, the distance to the city center as well as the difficulty of transportation to these districts, there have not been conducted any detailed studies about $L$. botrana until now.

Field monitoring of L. botrana populations in Turkey is generally made by using sticky trap containing sex pheromone lures and required repeated field surveys by a human expert to report the total number of males captured in traps. As we mentioned before, this is a labor-intensive, time consuming and expensive activity. In this context, to prevent these losses, the aim of this study was to design a remote monitoring system for $L$. botrana to monitor its population in field conditions in real-time without visiting.

\section{Material and Methods}

\section{Construction of Pheromone Traps}

In Hadim, four different vineyards, each were 10 da, were selected and one pheromone trap was constructed each vineyard in order to monitor the adult moth of $L$. botrana. Due to the less production in Taşkent, one vineyard, which was $10 \mathrm{da}$, was selected and one pheromone trap was constructed. Totally five pheromone traps were placed in five different vineyards. All pheromone traps were consisting of camera and the monitoring system by means of these cameras were prepared. The delta shape was protected in our camerabased pheromone trap as much as possible and the protection of the traps was provided against all unfavorable weather conditions. The traps were controlled once, when it's necessary twice, a month and the lures were replaced with the new once per month.

\section{Remote Monitoring of Pheromone Traps}

Each pheromone trap was controlled every day (at 12:00-14:00) by means of internet, screenshotted and the captured adult moths were counted manually. The adult moths counted in the previous screenshot was subtracted from the next one, thereby a detailed population development of $L$. botrana was detected. In the construction of camera-based pheromone trap, HD camera (Figure 1a), solar cell (Figure 1b), 12v 7Ah battery (Figure 1c), charging unit (Figure 1d), 3G GPRS modem (Figure 1e) were used.

All these components were put together and camerabased pheromone trap was constructed for remote monitoring the adult population of L. botrana. In the construction of camera-based pheromone traps, HD camera was preferred for high-resolution images. A solar cell, battery and charging unit were integrated in order to supply energy of this camera. A GPRS modem was used for remote monitoring the camera image or import it in a picture format. The environmental temperature and humidity were recorded by a HOBO.

\section{Results and Discussion}

\section{Coordinates of Camera-Based Pheromone Traps}

The coordinates of the traps which were constructed in Hadim and Taşkent for remote monitoring of the adult population development of L. botrana by means of camera were shown in Table 1.

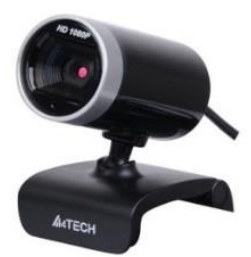

(a)

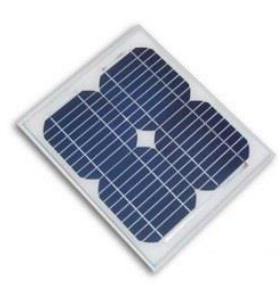

(b)

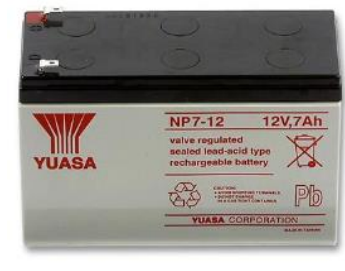

(c)

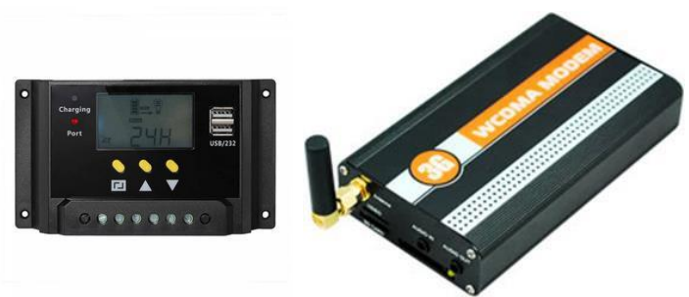

(d) (e)

Figure 1 a) HD camera, b) solar cell, c) 12v 7Ah battery, d) charging unit, e) 3G GPRS modem 
Table 1 Coordinates of the camera-based pheromone traps

\begin{tabular}{l|cc}
\hline \multicolumn{1}{c|}{ Name of traps } & Coordinates & Altitude $(\mathrm{m})$ \\
\hline Hadim -1 & $37^{\circ} 2^{\prime} 27^{\prime \prime} \mathrm{N}, 32^{\circ} 38^{\prime} 38^{\prime \prime} \mathrm{E}$ & 872 \\
Hadim -2 & $37^{\circ} 2^{\prime} 18^{\prime \prime} \mathrm{N}, 32^{\circ} 38^{\prime} 28^{\prime \prime} \mathrm{E}$ & 829 \\
Hadim -3 & $37^{\circ} 2^{\prime} 13^{\prime \prime} \mathrm{N}, 32^{\circ} 38^{\prime} 49^{\prime \prime} \mathrm{E}$ & 825 \\
Hadim -4 & $37^{\circ} 2^{\prime} 20^{\prime \prime} \mathrm{N}, 32^{\circ} 38^{\prime} 60^{\prime \prime} \mathrm{E}$ & 822 \\
Taşkent & $36^{\circ} 55^{\prime} 4^{\prime \prime} \mathrm{N}, 32^{\circ} 33^{\prime} 26^{\prime \prime} \mathrm{E}$ & 1259 \\
\hline
\end{tabular}

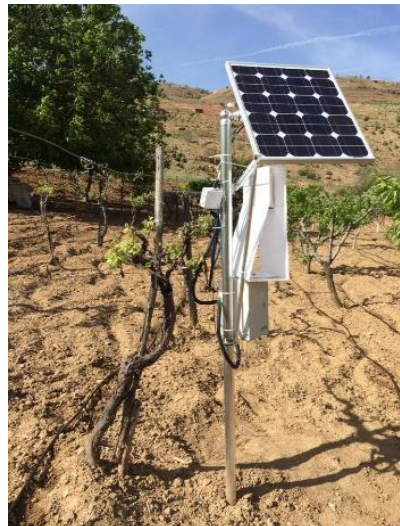

(a)

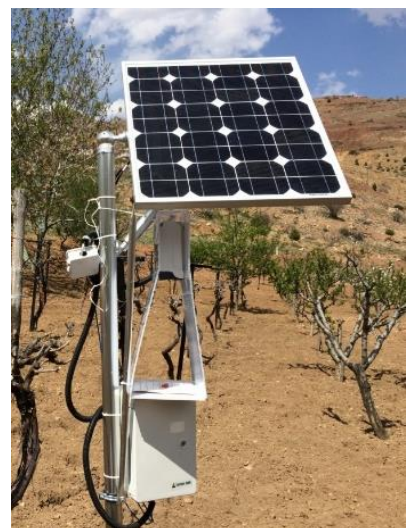

(b)

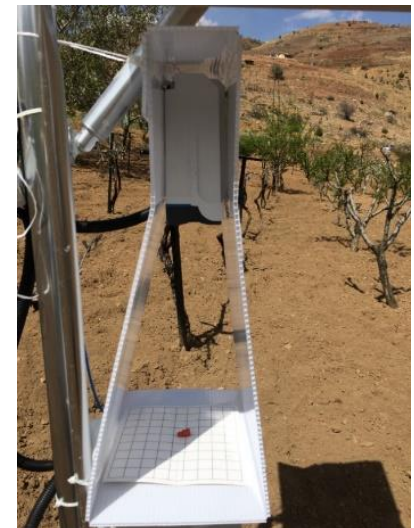

(c)

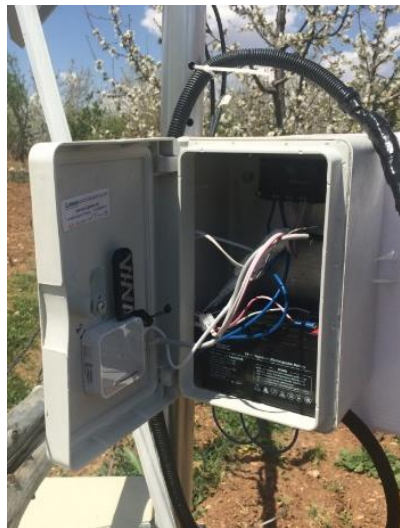

(d)

Figure 2 a, b) Camera-based pheromone trap, c) Camera and pheromone lure, d) Battery, charging unit and 3G GPRS modem

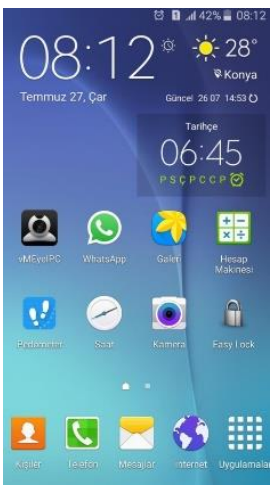

(a)

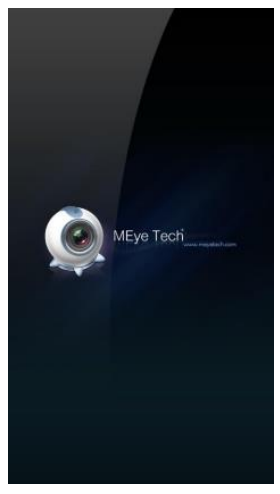

(b)

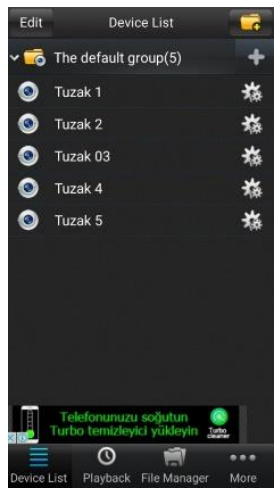

(c)

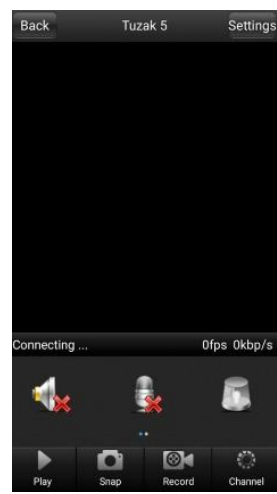

(d)

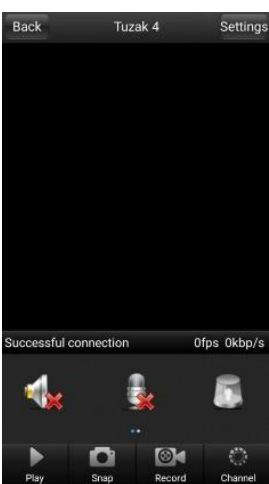

(e)

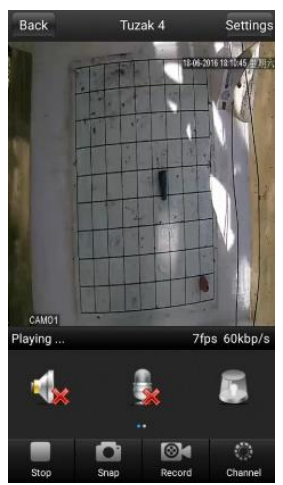

(f)

Figure 3 a) vMEyeIPC program, b) launching vMEyeIPC program, c) introducing the cameras, d) connecting to the camera, e) establishing of a successful connection, f) live view of the trap

Camera-Based Pheromone Traps in Hadim and Taşkent and Connecting to The Traps

In order to remote monitoring of adult moth population of L. botrana in Hadim and Taşkent vineyards, camera, solar cell, battery, charging unit and 3 GPRS modem were integrated on a standard pheromone trap. These traps were installed on an aluminum pole and placed on vineyards (Figure 2). All the traps were placed on April 6 ${ }^{\text {th }}, 2016$ in Hadim and Taşkent.

The fluctuation of the population of $L$. botrana was monitored via mobile phone or computer once a day (12:00-14:00) and took an image. Before connecting to the cameras, we need to download the program named "vMEyeIPC" (it can be downloaded for free from Google Play) to our mobile phone or computer (Figure 3a). After downloading, we need to launch the program (Figure $3 \mathrm{~b}$ ) and introduce the cameras (Figure 3c). When we want to connect a camera from the camera list, we need to click on it and wait for a while for connecting (Figure 3d). After a short period of time, a successful connection is established (Figure 3e). The program provides not only taking images but also recording.
Population Development of Lobesia Botrana in Hadim and Taşkent

The adult population development of L. botrana in Hadim and Taşkent vineyards was monitored daily during their entire occurrence period from April $07^{\text {th }}$ to September $29^{\text {th }} 2016$ by camera-based pheromone traps. The results of Hadim-1 were shown in the Figure 4.

The traps were placed on April 6 ${ }^{\text {th }}, 2016$ in Hadim. The first $L$. botrana adults were captured on April $7^{\text {th }} 2016$ and 9 adults/trap were recorded on April 14 ${ }^{\text {th }} 2016$ in Hadim-1. After this date, the population started to decrease until the beginning of June (June $2^{\text {nd }} 2016$ ) and a peak occurred on June $23^{\text {rd }} 2016$ ( 15 adults/week). The numbers of trapped adults decreased since the end of June and approximately one month later a new peak observed on July $28^{\text {th }} 2016$ (26 adults/week). The next peak was on September $8^{\text {th }}(22$ adults/week) and the population of the pest declined steadily towards the end of the production season. It has been detected that the pest peaked four times in Hadim-1 throughout the whole production season (Figure 4).

The results of Hadim-2 were shown in the Figure 5. Like in Hadim-1, the first L. botrana adults were captured 
on April $7^{\text {th }} 2016$ and reached its first peak on April $14^{\text {th }}$ 2016 (16 adults/week). The population decreased after this date and since the mid-June (June 16 ${ }^{\text {th }} 2016$ ) the adult population increased and the second peak was observed on June $30^{\text {th }} 2016$ (7 adults/week). The next peak of the population was detected about one month later on August $4^{\text {th }} 2016$ (18 adult/week) and the last one was on September $15^{\text {th }} 2016$, thus the pest peaked four times throughout the production season (Figure 5).

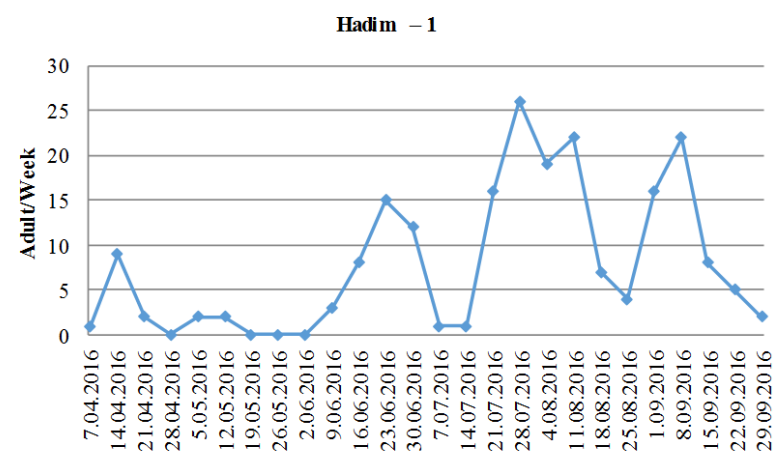

Figure 4 The adult population development of Lobesia botrana in camera-based pheromone trap in Hadim-1

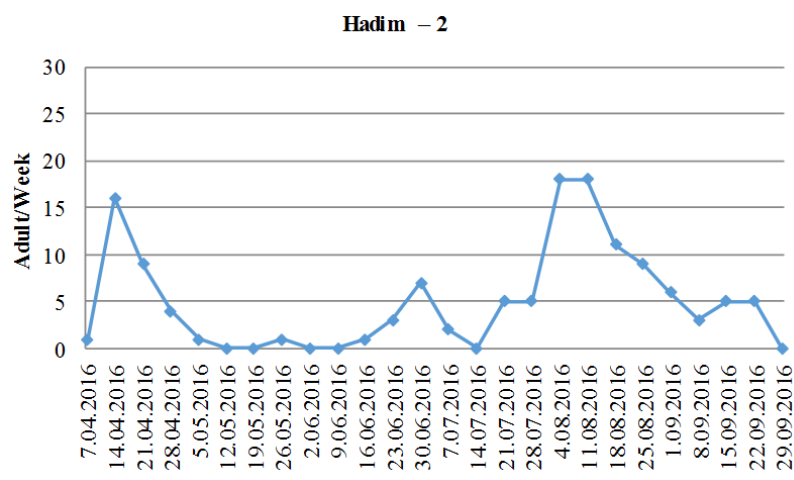

Figure 5 The adult population development of Lobesia botrana in camera-based pheromone trap in Hadim-2

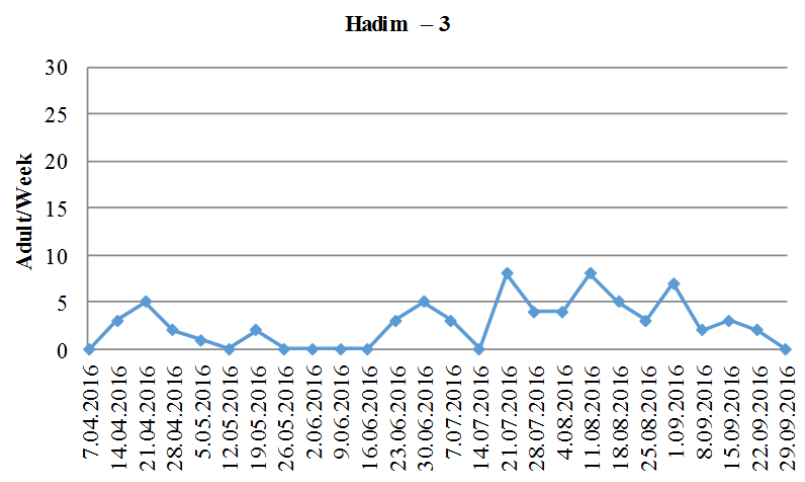

Figure 6 The adult population development of Lobesia botrana in camera-based pheromone trap in Hadim-3

In Hadim-3, the first L. botrana adults were captured on April $8^{\text {th }} 2016$ and reached its first peak on April $21^{\text {st }}$ 2016 (5 adults/week). Although it was detected a mini peak on May $19^{\text {th }}$ ( 2 adults/week), the population was quite low till mid-June. Since mid-June, population increased and peaked on June $30^{\text {th }}$ (5 adults/week). The other peaks of the population was on July $21^{\text {st }}$ (8 adults/week), August $11^{\text {st }}(8$ adults/week) and the last one was on September $1^{\text {st }}$ (7 adults/week).
In the last vineyard of Hadim (Hadim-4), the first $L$. botrana adults were captured on April $7^{\text {th }} 2016$ and reached the first and only peak on April $21^{\text {st }}$ ( 7 adults/week) due to pesticide applications regularly against $L$. botrana. So the pest has hardly been seen again in this vineyard since May $12^{\text {th }} 2016$ (Figure 7).

In Taşkent, due to the altitude is higher than Hadim, the first L. botrana adults were captured on April 17 2016 . The first peak of the population was on May $28^{\text {th }}$ (3 adults/week), the second and the highest was on June $16^{\text {th }}$ (15 adults/week). The population was rapidly decreased after this time till July $28^{\text {th }}$. The last peak was on August $18^{\text {th }}$ and the adults captured in the traps were gradually decrease towards the end of the season (Figure 8).

Recently, the potential using of cameras for monitoring insect pest have intensified and several camera-based pheromone traps have been designed and used to monitor insect pest. One of the first users of camera on insect trap is Kondo et al. (1994). They designed an automatic device with a camera to record the changes in pheromone trap catches. They used a sticky trap and a water-pan to capture Chilo suppressalis and Spodoptera litura moths, respectively. So they could easily detect hourly changes in moth numbers by their photographs.

While designing a camera integrated trap, you could use existing conventional traps with some modifications or design a new one. As in our study, some designs of new automatic traps inspired by the conventional ones (López et al., 2012; Potamitis et al., 2014; Selby et al., 2014). We designed our trap based on delta pheromone trap, which is conventionally used for monitoring of L. botrana population.

In this study we counted the captured moths manually, like in Guarnieri et al. (2011) and Rassati et al. (2016), from the images taken daily. But in most of the other studies, the pests were counted automatically by image processing software (Okuyama et al., 2011; Fukatsu et al., 2012; Priya et al., 2013; Upadhyay and Ingole, 2014; Ding and Taylor, 2016; Goldshtein et al. 2017). Manual counting has an advantage of accuracy in the results with no doubt. On the contrary, automatic counting may need to be verified by a human expert.

Some studies proved the applicability of automatic monitoring of pest insect on the field (Tirelli et al., 2011; Priya et al., 2013; Upadhyay and Ingole, 2014). Their system based on an imaging device operated by a wireless sensor network. It is able to automatically obtain and transmit images to a remote host station. When insect population exceed threshold, the station evaluates the insect density and produces an alarm.

The only study about L. botrana was done by Facello and Cavallo (2013). They aimed to design and construct a device for remote monitoring of L. botrana and Eupecilia ambiguella. Their system was based on a camera and a LED illuminator. The recorded files were stored on a disk and a free file hosting service on the web. Thus, authorized users can easily access to records from any device with internet connectivity. The power of the system was supplied by a solar panel and the users could easily remote visual check the traps.

This system not only used in fields (Raphael and Maheswari, 2016; Miranda et al., 2014), orchards (Kim et al., 2011; Hari, 2014) or vineyards (Facello and Cavallo, 
2013), but also used in greenhouse crops for reducing pesticide use. Martin et al. (2008), tried to define a new system for early pest detection in greenhouse. The system was based on video analysis. They targeted to detect white flies and aphids.

Consequently, as in our study, the common advantages of all these studies are; to make a more effective monitoring, to reduce the monitoring costs and to save time.

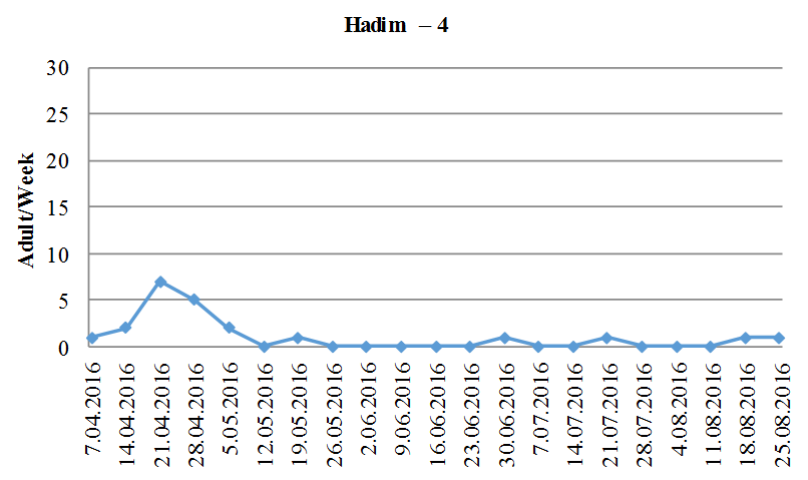

Figure 7 The adult population development of Lobesia botrana in camera-based pheromone trap in Hadim-4

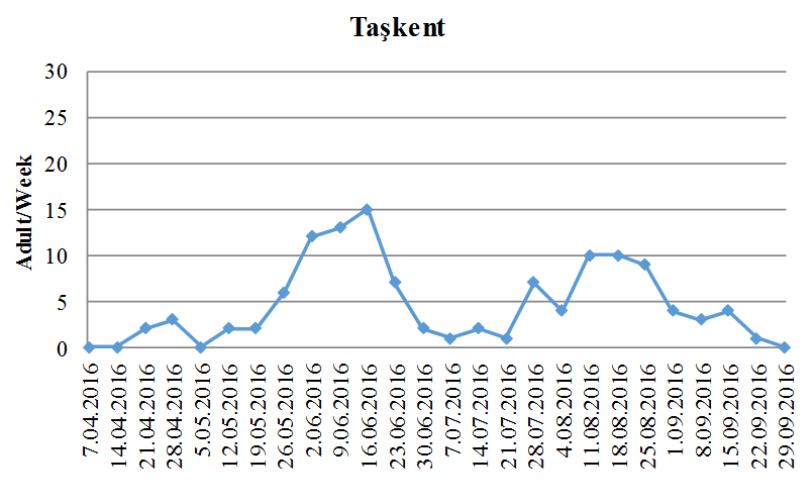

Figure 8 The adult population development of Lobesia botrana in camera-based pheromone trap in Taşkent

\section{Conclusion}

It is the first camera-based pheromone trap developed for L. botrana monitoring in Turkey. The pest, L. botrana, was detected in all surveyed areas in Hadim and Taşkent, which consist of approximately $41 \%$ of the total vineyards in Konya province. Since their geographical location and difficulties of transportation, no detailed research has been done about this pest. The management of L. botrana is based on early warning system. The crucial point of this management is monitoring the adult pest by pheromone traps. The traps must be controlled 2-3 times/week until the first adult pest was captured and 1-2 times/week after the first adult was captured in order to get a successful management. But when we take into account the distance from the city center of these two districts (Hadim and Taşkent 125 and $135 \mathrm{~km}$, respectively) it's really a labor-, time- and cost-consuming (car rental, fuel, daily pay and etc.) activity. However with the help of the cameras that we integrated on the pheromone traps, not only saved cost but also the changes in the pest population was monitored more effectively.
If we need to make a cost calculation; the total cost of a camera-based pheromone trap is about $250 \$$. The cost of field survey to Hadim and Taşkent once a week with the project team for monitoring the pest is around $125 \$$ instead of using camera-based pheromone traps. The cost of visiting to the field that must be done for six months (once a week from April to September) is more expensive than the camera-based pheromone traps. Moreover, besides the financial loss, when we consider the loss of time which cannot be measured with money, it was determined that the camera-based pheromone traps were much more advantageous.

The main objective of this study was the construction and working properly of the camera-based pheromone traps. It was revealed that the camera-based pheromone traps can be remote controlled successfully. Nevertheless, some points need to be paid attention to ensure that the camera working properly without interruption. For example, the battery cannot be charged enough and the system closed when the cloudy days are so long. So, the number of sunny days in the field where these traps will be constructed must be more. In addition, the signal strength of your internet provider in the field where the traps will be constructed is really important in terms of connecting to the camera. It's also recommended that the camera-based pheromone traps must be constructed near farmer's house in terms of safety.

Monitoring of L. botrana has been dependent on a traditional sex pheromone trap, especially delta-trap, until now. This method requires periodic visits to the field by farmers or by a human expert in order to visual observation and recording of males captured in the traps. This activity is labor intensive and therefore costly and takes an amount of time. We believe this traditional method can be replaced by the remote monitoring traps presented in this study. Our system can significantly reduce the costs, time and labor consuming, increased the effectiveness and the efficiency of the trap when compared to the traditional monitoring methods. This study revealed the applicability of camerabased pheromone traps for the monitoring of L. botrana by solving logistical problems, reducing or avoiding direct field observations, reducing cost and saving time. Furthermore, this camera-based pheromone trap is not special for only L. botrana, it could be used in monitoring of a wide variety of pest insects with minor modifications. Further research is still needed to enhance the system and to detect the applicability on other insect pests.

\section{Acknowledgments}

This study was supported by the Scientific and Technological Research Council of Turkey - TÜBİTAK (Project number: 1150822).

\section{References}

Anonymous. 2015a. Data of Konya Directorate of Provincial Food Agriculture and Livestock. (Web page: http://www.illerarasimesafe.com/), (Accessed date: 15 March 2015).

Anonymous. 2015b. Data of Konya Directorate of Provincial Food Agriculture and Livestock. (Web page: http://konya.tarim.gov.tr/hadim/Menu/25/Tarim), (Accessed date: 15 March 2015). 
Anonymous. 2015c. Data of Konya Directorate of Provincial Food Agriculture and Livestock. (Web page: http://konya.tarim.gov.tr/taskent/Menu/2/Ilcemiz), (Accessed date: 15 March 2015).

Anonymous. 2015d. Data of Konya Directorate of Provincial Food Agriculture and Livestock. (Web page: http://konya.tarim.gov.tr/Menu/6/Tarimsal-Yapi), (Accessed date: 15 March 2015).

Anonymous. 2017. OIV Statistical Report on World Vitiviniculture, 2017. world vitiviniculture situation. (Web page: http://www.oiv.int/public/medias/5479/oiv-en-bilan2017.pdf), (Accessed date: 29 December 2017).

Arslan S. 2015. Republic of Turkey Ministry of Food Agriculture and Livestock Agricultural Economic and Policy Development Institute. Ürün Raporu, Üzüm. (Web page: http://www.tepge.gov.tr/Dosyalar/Yayinlar/df75be1354b64d a684b9322c053c4b0e.pdf), (Accessed date: 30 December 2017).

Azfar S, Nadeem A, Basit A. 2015. Pest detection and control techniques using wireless sensor network: A review. J. Entomol. Zool. Stud., 3 (2): 92-99.

Ding W, Taylor G. 2016. Automatic moth detection from trap images for pest management. Comput. Electron. Agric., 123: 17-28.

Facello A, Cavallo E. 2013. Insects remote detection in pheromones traps. EFITA-WCCA-CIGR Conference. Turin, Italy, 24-27 June 2013. 400-408.

Fukatsu T, Watanabe T, Hu H, Yoichi H, Hirafuji M. 2012. Field monitoring support system for the occurrence of Leptocorisa chinensis Dallas (Hemiptera: Alydidae) using synthetic attractants, Field Servers, and image analysis. Comput. Electron. Agric., 80: 8-16.

Goldshtein E, Cohen Y, Hetzroni A, Gazit Y, Timar D, Rosenfeld L, Grinshpon Y, Hoffman A, Mizrach A. 2017. Development of an automatic monitoring trap for Mediterranean fruit fly (Ceratitis capitata) to optimize control applications frequency. Comput. Electron. Agric., 139: 115-125.

Guarnieri A, Maini S, Molari G, Rondelli V. 2011. Automatic trap for moth detection in integrated pest management. Bull. Insectology, 64(2): 247-251.

Hari K, 2014. Possibilities in Development of Environmentally Friendly Control of Fruit Moths in Hungary. (Doctoral thesis) Department of Fruit Sciences, Faculty of Horticultural Science, Corvinus University of Budapest, Budapest, $15 \mathrm{pp}$.

Jiang, JA, Tseng CL, Lu FM, Yang EC, Wu ZS, Chen CP, Lin SH, Lin KC, Liao CS, 2008. A GSM-based remote wireless automatic monitoring system for field information: A case study for ecological monitoring of the oriental fruit fly, Bactrocera dorsalis (Hendel). Comput. Electron. Agric., 62: 243-259.

Jones O, 2014. Pheromones and other semiochemicals: Essential tools for IPM. Int. Pest Contr., 56(2):88.

Kim Y, Jung S, Kim Y, Lee Y, 2011. Real-time monitoring of oriental fruit moth, Grapholita molesta, populations using a remote sensing pheromone trap in apple orchards. J. Asia Pac. Entomol., 14: 259-262.

Kondo A, Sano T, Tanaka F. 1994. Automatic record using camera of diel periodicity of pheromone trap catches. Jpn. J. Appl. Entomol. Z., 38(3): 197-199.
Lopez O, Rach MM, Migallon H, Malumbres MP, Bonastre A, Serrano JJ. 2012. Monitoring pest insect traps by means of low-power image sensor technologies. Sensors, 12: 1580115819.

Lucchi A, Sambado P, Royo ABJ, Bagnoli B, Benelli G. 2018a. Lobesia botrana males mainly fly at dusk: video cameraassisted pheromone traps and implications for mating disruption. J. Pest Sci., 91(4): 1327-1334.

Lucchi A, Sambado P, Royo ABJ, Bagnoli B, Conte G, Benelli G. 2018b. Disrupting mating of Lobesia botrana using sex pheromone aerosol devices. Environ. Sci. Pollut. Res., 25:22196-22204.

Mamay M, Çakır A. 2014. Şanlıurfa merkez ilçe bağlarında salkım güvesi [Lobesia botrana Denis \& Schiffermüller (Lepidoptera: Tortricidae)]'nin ergin popülasyon değişimi ve bulaşma oranının belirlenmesi. Bit. Kor. Bült., 54(2): 103114.

Martin V, Moisan S, Paris B, Nicolas O. 2008. Towards a video camera network for early pest detection in greenhouses. Endure International Conference. La Grande-Motte, France, 12-15 October 2008. pp. 12-15.

Miranda JL, Gerardo BD, Tanguilig IIIB T. 2014. Pest detection and extraction using image processing techniques. Int. J. Comput. Comm. Eng., 3(3): 189-192.

Okuyama T, Yang EC, Chen CP, Lin TS, Chuang CL, Jiang JA. 2011. Using automated monitoring systems to uncover pest population dynamics in agricultural fields. Agric. Syst., 104: 666-670.

Potamitis I, Rigakis I, Fysarakis K. 2014. The electronic mcpahil trap. Sensors, 14:22285-22299.

Potamitis I, Rigakis I. 2015. Smart traps for automatic remote monitoring of Rhynchophorus ferrugineus (Coleoptera: Curculionidae). PeerJ PrePrints, (No. e1651).

Priya CT, Praveen K, Srividya A. 2013. Monitoring of pest insect traps using image sensors and dspic. Int. J. Eng. Trends Tech., 4 (9): 4088-4093.

Raphael MM, Maheswari R. 2016. Automatic monitoring of pest trap. Int. J. Adv. Res. Elec., Electr. Instr. Eng., 5 (4):24702473.

Rassati D, Faccoli M, Chinellato F, Hardwick S, Suckling DM, Battisti A. 2016. Web-based automatic traps for early detection of alien wood-boring beetles. Entomol. Exp. Appl., 160: 91-95.

Selby RD, Gage SH, Whalon ME. 2014. Precise and low-cost monitoring of plum curculio (Coleoptera: Curculionidae) pest activity in pyramid traps with cameras. Environ. Entomol., 43(2): 421-431.

Tirelli P, Borghese NA, Pedersini F, Galassi G, Oberti R. 2011. Automatic monitoring of pest insects traps by Zigbee-based wireless networking of image sensors. Instrumentation and Measurement Technology Conference. Hangzhou, China, 1012 May 2011, pp. 1192-1196.

Turanlı F. 2017. Bağ zararlıları ve mücadeleleri. Nevşehir Bilim ve Teknoloji Dergisi, 6: 112-121.

Upadhyay AJ, Ingole PV. 2014. Automatic monitoring of pest insects traps using image processing. Indones. J. Elec. Eng. Comput. Sci., 12(8): 5779-5783. 